\title{
The Effect of Socio-Demographic and Cultural Features on Traditional, Complementary and Alternative Medicine in Healthcare Students
}

\section{Sağlık Öğrencilerinde Sosyo-Demografik ve Kültürel Özelliklerin Geleneksel, Tamamlayıcı ve Alternatif Tıp Üzerine Etkisi}

\author{
Çağla Yiğitbaş', @ Aliye Bulut ${ }^{2}$ \\ 'Giresun University, Faculty of Health Sciences, Department of Midwifery, GiresunTurkey \\ ${ }^{2}$ Gaziantep Islamic Science and Technology University, Department of Midwifery, Gaziantep/Turkey,
}

\begin{abstract}
Objective: The aim of the research is to determine the impact of socio-demographic-cultural characteristics and educational background on the approach to Traditional, Complementary and Alternative Medicine (TCAM) practices among healthcare students.

Material and Method: The research was designed as a quantitative and descriptive-cross-sectional study and carried out with health educated students from two different universities.

Results: $59.4 \%$ of the participants reported using TCAM; $21.2 \%$ reported having experienced problems with the practices they applied, while $68.8 \%$ advice this method to others. The variables of age, university, marital status, long-term location of residence, perceived income, chronic disease status, smoking, source of traditional, complementary and alternative medicine information, any problems following TCAM use and post- TCAM experience were found effective.
\end{abstract}

Conclusion: TCAM training should be included in the education programs of students receiving health education so as to provide them with accurate information on the matter.

Keywords: Complementary therapies, alternative medicine, cultural characteristics, health education
Öz

Amaç: Sağlık eğitimi alan öğrencilerde, sosyodemografik-kültürel ve konuya ilişkin eğitim alıp almamaya yönelik özelliklerin Geleneksel Tamamlayıcı Alternatif Tıp (GETAT) uygulamalarına yaklaşımlarındaki etkisini belirlemektir.

Gereç ve Yöntem: Nicel ve tanımlayıcı-kesitsel tipte olan araştırma ik farklı üniversitenin sağlık eğitimi alan öğrencileriyle gerçekleştirilmiştir Bulgular: Katılımcıların \%59.4'ü GETAT kullandığını, \%21.2'si yaptığı uygulamadan dolayı sorun yaşadığını, \%68.8'i başkalarına da bu yöntemleri tavsiye ettiğini belirtmiştir. Yaş, üniversite, medeni durum, hayatının uzun süre ile geçtiği yer, gelir düzeyi algısı, kronik hastalık durumu, sigara alışkanlığı, GETAT konusundaki bilgi kaynağı, GETAT nedeniyle sorun yaşayıp yaşamama durumu ve GETAT sonrası deneyim değişkenleri etkili bulunmuştur.

Sonuç: GETAT eğitimleri konuya ilişkin doğru bilgilerin kazanımı için sağlık eğitimi alan öğrencilerin eğitim programlarında olmalıdır.

Anahtar Kelimeler: Geleneksel tıp, tamamlayıcı tıp, alternatıf tıp, sağlık eğitimi 


\section{INTRODUCTION}

Complementary, traditional, conventional, or alternative methods that are defined under the main heading of Traditional and Complementary Alternative Medicine (TCAM) have existed for centuries. ${ }^{[1,2]}$ However, TCAM practices are still debated in many countries around the world by policymakers, health professionals and public with regard to matters such as security, effectiveness, availability, protection and organization. ${ }^{[3]}$ The World Health Organization (WHO) defines Traditional Medicine (TM) as the sum total of knowledge, skills and practices based on the theories, beliefs and experiences indigenous to different cultures. ${ }^{[4]}$ While complementary/ alternative medicine (CM) is defined as a broad set of healthcare practices that are not part of that country's own tradition or conventional medicine and are not fully integrated into the dominant healthcare system. ${ }^{[5]}$ Their union is defined as traditional and complementary medicine (T\&CM). In mid2017, WHO's T\&CM unit was renamed to include the term "Integrative Medicine", to cover the integrative approaches of both T\&CM and conventional medicine regarding policy, information and practices. ${ }^{[6]}$

T\&CM is becoming more popular in all stages of health, especially in the preventive and therapeutic areas. ${ }^{[7,8]}$ TCAM is widely used worldwide for various reasons such as accessibility, suitability, home-use, cultural compatibility, costeffectiveness, and as a way of dealing with non-communicable chronic diseases. The report published in 2012 by WHO Traditional Medicine Strategy touched upon issues such as the limited number of research on the subject, absence of control and regulatory mechanisms for advertisements, absence of product-related control mechanisms, inadequate financial support for research, lack of communication between the health authorities on the subject, and inadequate training received by those applying these methods, 3 emphasizing the need for improvements. ${ }^{[9]}$

The rate of TCAM use at least once a year is above $40 \%$ in countries such as America, Germany, Switzerland, Cuba, Japan and Chile. ${ }^{[10]}$ Some countries have included T\&CM practices in their curricula. The use of T\&CM in regions such as Asia, Africa, Australia and North America is much higher than European countries that frequently opt to these methods. ${ }^{[3]}$

The rate of TCAM use is $48.2 \%$ in Australia, $49.3 \%$ in France, and $70.4 \%$ in Canada; while, among developing countries, it is around $70.0 \%$ in China, $40.0 \%$ in Colombia and $80.0 \%$ in African countries. ${ }^{[11]}$

Turkey is a country with national policies, regulations, research institution and an application hospital on TCAM. Only a physician is given the authority to apply TCAM. However, there is no data regarding the percentage of physicians performing these practices and their ratio to the total share of traditional medicines. Individuals often seek non-physician healthcare professionals for counseling, which is a widely accepted concept in Turkey. In this context, it is important to identify individuals' perceptions, awareness and practices towards the matter.
Participating students, who will take part in health services as non-physician healthcare personnel in the future, from two different universities who receive and do not receive elective courses on TCAM were compared with the aim to determine their approaches within the scope of their socio-demographic and cultural characteristics.

\section{MATERIAL AND METHODS}

The research was designed as a quantitative, descriptive and cross-sectional study. Study data were collected through a questionnaire during the 2018-2019 academic year. Ethical and institutional permissions were obtained prior to the research and voluntary participation was sought. The establishment year and academic structure of the universities where the research was conducted were similar. A University is located in the Eastern Black Sea region on Turkey, whereas B University is located in the Eastern Anatolia region. A University exhibits similar cultural characteristics with the countries in the west of Turkey, whereas B university exhibits similar cultural characteristics with the countries in the east of Turkey The majority of university students consisted of those coming from cities in the vicinity of the region where the university is located. These universities were purposefully selected for easy sampling. A university has a population of 690 students studying healthcare. A total of 588 people participated in the study (response rate: $85.21 \%$ ). B University has a population of 675 students studying healthcare. A total of 570 people participated in the study (Response rate: $84.44 \%$ ).

\section{Data Collection Tools}

Data were collected using a questionnaire form developed by the researchers. The questionnaire form included questions investigating the socio-demographic and cultural characteristics of the participants such as which university they attended, class, department, age, gender, marital status, family type, mother and father's educational background and occupation, habits, disease history, previous knowledge about TCAM methods, previous applications, familiarity with TCAM methods, history of usage, any associated problems experienced, and recommendations if any.

\section{Data Collection}

Prior to the study, approval was obtained from the Research Ethics Committee of Bingöl University (26/03/2018:10) and the deanships of the schools where students were enrolled. Participating students were given an Informed Consent Form attached to the questionnaire for the explanation of the scope of the study. The study data were collected by the researchers in the first 20 minutes of any lesson.

Informed Consent Form: The form explains that all individuals are completely free to decide whether to participate in the research and they can withdraw from the research at any time and that their identity will be kept confidential at all stages of the research, but the information obtained will be used. 


\section{Statistical Analysis}

The SPSS-22 package software was used to evaluate the study data and perform error checks, tables and statistical analyses. TCAM questions were the dependent variables of the study, whereas the independent variables were the socio-demographic-cultural characteristics. Descriptive statistics were expressed as number, percentage, median and min-max values. In the study, binary logistic regression analysis was performed; the means were presented with standard deviation (Mean $\pm S D$ ), and the value of $p<0.05$ was considered statistically significant.

\section{RESULTS}

The mean age of the participants was $20.83 \pm 1.67$ (min-max: 18 30, Median: 21). Descriptive characteristics of the participants are shown in Table 1. In the study, 31.4\% of the participants were female. This rate is similar to the ratio of faculty students in Turkey where three out of every four people studying in fields such as nursing and mid wifery are female. The rate of smokers is $17.4 \%$, while the rate of those who drink alcohol is $3.1 \%$. The participants were asked which TCAM methods they used. Out of all participants, 34.6\% reported not having previously heard about prolotherapy, 31.6\% about larvae application, $31.5 \%$ about ozone therapy, $31.4 \%$ about homeopathy, $30.2 \%$ about mesotherapy, $27.3 \%$ about osteopatia, $26.2 \%$ about chiropractic, $21.6 \%$ about acupuncture, $21.5 \%$ about phytotherapy, $20.7 \%$ about leech therapy and reflexology, $19.6 \%$ about cupping, $16.5 \%$ about meditation, $17.4 \%$ about yoga, and $5.5 \%$ about breathing exercises. On the other hand, $51.6 \%$ of the participants reported using breathing exercises, $45.5 \%$ prayer, $44.8 \%$ massages, $39.3 \%$ music therapy, $37.9 \%$ aerobics, 33.9\% meditation, 33.0\% nutrition therapy, 32.0\% thermal spring, $30.0 \%$ yoga, $28.7 \%$ reflexology, $28.2 \%$ cupping, $27.9 \%$ phytotherapy, $27.2 \%$ aromotherapy, $26.5 \%$ leech therapy, $25.0 \%$ chiropractic, $24.6 \%$ acupuncture, $23.8 \%$ hypnosis, $21.9 \%$ osteopatia, $20.6 \%$ mesotherapy, $19.9 \%$ homeopathy, $18.0 \%$ ozone treatment, $17.9 \%$ larval treatment, and $16.3 \%$ prolotherapy.

As can be seen in Table 2, the upmost reasons for using TCAM practices were; believing it will provide additional benefit to the medical method (84.2\%), believing it will prevent the progression of the disease (72.9) and believing that it will promote health/well-being and provide physical relief (72.8\%).

Table 3 demonstrates the participants' TCAM practices. The rate of those who use TCAM is $59.4 \%$, and the rate of those receiving this training as an elective course is $5.3 \%$. It was observed that the participants picked "seeing users benefit from it" as the upmost reason for using TCAM methods. On the other hand, $33.7 \%$ stated that "acknowledged specialists should be preferred" for TCAM. The rate of those experiencing problems due to the use of TCAM is $21.2 \%$. The rate of those saying "I would give up medical treatment and use TCAM alone if I believed it was necessary" is $8.1 \%$.

\begin{tabular}{|c|c|c|c|}
\hline \multicolumn{2}{|l|}{ Characteristics } & \multirow{2}{*}{$\begin{array}{c}\text { Number } \\
588\end{array}$} & \multirow{2}{*}{$\begin{array}{c}\% \\
50.8\end{array}$} \\
\hline \multirow{2}{*}{ University } & A University & & \\
\hline & B University & 570 & 49.2 \\
\hline \multirow{2}{*}{$\begin{array}{l}\text { Age } \\
\text { (Median: 21) }\end{array}$} & Under 20 years of age & 517 & 44.6 \\
\hline & Above 21 years of age & 641 & 55.4 \\
\hline \multirow{2}{*}{ Gender } & Female & 764 & 31.4 \\
\hline & Male & 364 & 68.6 \\
\hline \multirow{2}{*}{ Marital status } & Married & 68 & 5.9 \\
\hline & Single & 1090 & 94.1 \\
\hline \multirow{3}{*}{ Family type } & Nuclear & 879 & 750.9 \\
\hline & Extended & 269 & 23.2 \\
\hline & Broken & 10 & 0.9 \\
\hline \multirow{2}{*}{$\begin{array}{l}\text { Long-term } \\
\text { location of } \\
\text { residence }\end{array}$} & Rural setting & 370 & 32.0 \\
\hline & Urban setting & 788 & 68.0 \\
\hline \multirow{5}{*}{$\begin{array}{l}\text { Mother's Level } \\
\text { of Education }\end{array}$} & Literate, did not finish school & 288 & 24.9 \\
\hline & Primary school graduate & 534 & 46.1 \\
\hline & Secondary school graduate & 143 & 12.3 \\
\hline & Highschool graduate & 153 & 13.2 \\
\hline & University graduate & 40 & 3.5 \\
\hline \multirow{5}{*}{$\begin{array}{l}\text { Father's Level } \\
\text { of Education }\end{array}$} & Literate, did not finish school & 84 & 7.3 \\
\hline & Primary school graduate & 442 & 38.2 \\
\hline & Secondary school graduate & 217 & 18.7 \\
\hline & Highschool graduate & 329 & 28.4 \\
\hline & University graduate & 86 & 7.4 \\
\hline \multirow{2}{*}{ Smoking } & No & 957 & 82.6 \\
\hline & Yes & 201 & 17.4 \\
\hline \multirow{2}{*}{ Alcohol } & No & 1122 & 96.9 \\
\hline & Yes & 36 & 3.1 \\
\hline \multirow{2}{*}{$\begin{array}{l}\text { Drug } \\
\text { addiction }\end{array}$} & No & 904 & 78.1 \\
\hline & Yes & 254 & 21.9 \\
\hline \multirow{2}{*}{$\begin{array}{l}\text { Chronic } \\
\text { disease }\end{array}$} & No & 1069 & 92.3 \\
\hline & Yes & 89 & 7.7 \\
\hline
\end{tabular}

As seen in Table 4; the participants' age, university, marital status, long-term location of residence, perceived income, chronic diseases, smoking habit, source of TCAM information, whether or not experiencing problems due to TCAM, and postTCAM experience were all found effective, independently from each other $(p<0.05)$. The evaluation of the one-unit increase showed that having experienced problems due to TCAM use was 11.6 times; being at A university was 4.94 times; being single was 2.96 times; high expenses was 2.1 times; chronic disease was 2.0 times; not experiencing any improvements in previous experiences was 1.9 times, not noticing any results was 1.7 times; long-term residence in urban settings was 1.5 times and age was 1.4 times effective in not using TCAM $(p<0.05)$. The evaluation of the one-unit increase in using TCAM showed that the means of the internet as a source of TCAM information and previous education were 0.4 times; newspaper-book-magazine as the source of information was 0.2 times; and previous negative experience following TCAM practice was 0.3 times effective $(p<0.05)$. 
Table 2. Distribution of participants' responses to reasons for TCAM use ( $N=1158$ )

\begin{tabular}{|c|c|c|}
\hline Reasons for TCAM use & No n (\%) & Yes n (\%) \\
\hline It provides additional benefits to medical methods ( $n=1092)$ & $172(15.8)$ & $920(84.2)$ \\
\hline I believe it prevents the progression of the disease/has benefits $(n=1070)$ & $290(27.1)$ & $780(72.9)$ \\
\hline It promotes health/well-being $(n=1083)$ & $295(27.2)$ & $788(72.8)$ \\
\hline It provides physical relief $(n=1079)$ & $293(27.2)$ & $786(72.8)$ \\
\hline It improves the symptoms of the disease before medical treatment $(n=1050)$ & $317(30.2)$ & $733(69.8)$ \\
\hline I pay attention to the recommendations of friends and relatives $(n=1057)$ & $331(31.3)$ & $726(68.7)$ \\
\hline It helps to get rid of the feeling of hopelessness and despair $(n=1051)$ & $347(33.0)$ & $704(67.0)$ \\
\hline It strengthens the immune system $(n=1053)$ & $351(33.3)$ & $702(66.7)$ \\
\hline Medicinal treatment methods have side effects ( $n=1044)$ & $349(33.4)$ & $695(66.6)$ \\
\hline Any treatment that can cure the disease should be given a chance $(n=1042)$ & $367(35.2)$ & $675(64.8)$ \\
\hline It improves the quality of life $(n=1078)$ & $479(44.4)$ & $599(55.6)$ \\
\hline
\end{tabular}

Table 3. Distribution of participants' TCAM practices $(\mathrm{N}=1158)$

Characteristics

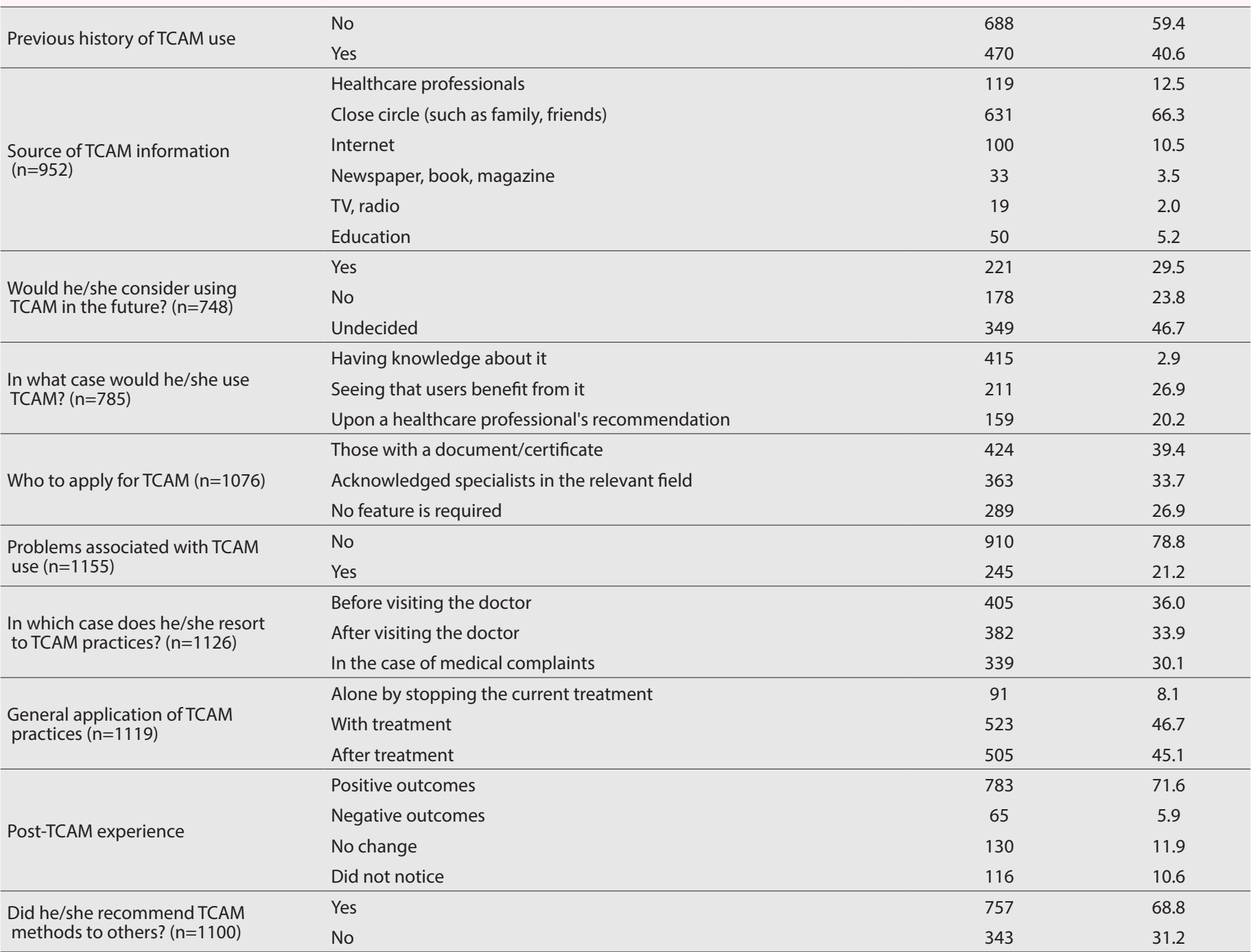




\begin{tabular}{|c|c|c|c|c|c|}
\hline Variable & & $\beta$ & $\mathbf{p}$ & OR & $95 \% \mathrm{Cl}$ \\
\hline Age (Numerical) & & 0.387 & 0.001 & 1.473 & $1.309-1.658$ \\
\hline \multirow{2}{*}{ University } & B University & & & 1.00 & \\
\hline & A University & 1.598 & 0.001 & 4.942 & $3.297-7.408$ \\
\hline \multirow{2}{*}{ Gender } & Male & & & 1.00 & \\
\hline & Female & -0.154 & 0.421 & 0.857 & $0.588-1.248$ \\
\hline \multirow{2}{*}{$\begin{array}{l}\text { Location of long-term } \\
\text { residence }\end{array}$} & Rural Setting & & & 1.00 & \\
\hline & Urban Setting & 0.439 & 0.017 & 1.551 & $1.081-2.225$ \\
\hline \multirow{3}{*}{ Perceived income } & Higher income & & 0.096 & 1.00 & \\
\hline & Higher Expenses & 0.758 & 0.042 & 2.135 & $1.026-4.440$ \\
\hline & Income equal to expenses & 0.519 & 0.153 & 1.681 & $0.825-3.424$ \\
\hline Smoking & Yes & -1.828 & 0.001 & 0.161 & $0.095-0.273$ \\
\hline \multirow{2}{*}{$\begin{array}{l}\text { Use of over-the- } \\
\text { counter medicines }\end{array}$} & No & & & 1.00 & \\
\hline & Yes & 0.057 & 0.770 & 1.059 & $0.720-1.558$ \\
\hline \multirow{6}{*}{$\begin{array}{l}\text { Source of TCAM } \\
\text { information }\end{array}$} & Healthcare professionals & & 0.012 & 1.00 & \\
\hline & Close circle & -0.275 & 0.304 & 0.760 & $0.450-1.283$ \\
\hline & Internet & -0.706 & 0.043 & 0.493 & $0.249-0.979$ \\
\hline & Newspaper, book, magazine & -1.526 & 0.004 & 0.217 & $0.077-0.616$ \\
\hline & TV, radio & -1.252 & 0.058 & 0.286 & $0.078-1.046$ \\
\hline & Education & -0.869 & 0.042 & 0.419 & $0.181-0.970$ \\
\hline $\begin{array}{l}\text { Problems following } \\
\text { TCAM use }\end{array}$ & No & & & 1.00 & \\
\hline
\end{tabular}

\section{DISCUSSION}

In 2012, the Traditional and Complementary Medicine Department was founded in Turkey and some regulations were included in the 2013-2017 Strategic Action Plan. In 2014, acupuncture, phytotherapy, apitherapy, homeopathy, hypnosis, leech therapy, cupping therapy, osteopathy, chiropractic, reflexology, musicotherapie, prolotherapy, maggot therapy and ozone therapy were legalized but not covered by public health insurance. Irelated training programs were allowed in educational research hospitals and universities under the scope of the Ministry of Health. Although TCAM methods are used nationally and have been under medical record for the past 30 years, there is no data on the rates of TCAM users on a country level. ${ }^{[12]}$ Consequently, the research data were compared with other researches conducted in the country on a local basis. The aim of the research is to determine the impact of relevant sociodemographic and cultural characteristics on TCAM practices among undergraduate healthcare students from two different cities with different cultures.
According to the WHO, more than three-quarters of the world's population trust complementary health approaches. [11] $59.4 \%$ of the participants reported using TCAM. The rate of TCAM use was found $60.5 \%$ in the study conducted in seven geographical regions of Turkey, while another study reported a rate of $28.7 \% \cdot{ }^{[11,13]} \mathrm{A}$ study conducted at a university in the United Arab Emirates found the rate of TCAM users as 34\%, whereas another study from Uganda found that $59 \%$ of the participants used TCAM. ${ }^{[14,15]}$ The rate of TCAM use varies from country to country and even in different regions of the same country.

In this research, the upmost TCAM methods of preference were praying, massage, aerobics and meditation. The participants reported not having previously heard of methods such as prolotherapy, homeopathy, ozone therapy and reflexology. Another domestic study demonstrated that cupping, acupuncture and hypnosis were the most preferred method among the participants, whereas chiropractic care and prolotherapy were the least. ${ }^{[16]}$ A study conducted in Indonesia reported spiritual-religious therapy, dietary supplements, 
music therapy and meditation as the most preferred TCAM methods among the participants, respectively. ${ }^{[17]}$ TCAM therapies provide an optimistic outlook and touch individuals' feelings and spirituality, going beyond the 'symptoms' defined by conventional medicine. ${ }^{[18]}$

The reasons for TCAM use vary depending on many factors. The reasons for TCAM use among the individuals included factors such as insufficient health assurance, side effects of some medications, complications and fees of medical interventions, belief in the insufficiency of medical interventions to improve immunity or provide treatment, and health promotion. ${ }^{[19]}$ In this study, the reasons for TCAM use among the participants included believing that it would provide additional benefit to the medical method, believing that the progression of the disease would be prevented and that it would promote health/well-being and provide physical relief. The reasons for not using TCAM included believing that medication treatment would be expensive or difficult; believing that it would not affect the quality of life or that it would not provide benefit to current methods. In another domestic study, the participants reported applying TCAM methods because they believed it would improve overall health and well-being; they saw that those who did were satisfied; and they were not satisfied with medical treatment, respectively. ${ }^{[1]]} \mathrm{A}$ study conducted in India demonstrated that approximately half of the participants used Ayurvedic and herbal therapies. ${ }^{[20]}$

In this study, the proportion of those receiving TCAM training as an elective course was $5.3 \%$, and the upmost reason for using TCAM methods was "seeing other users benefit from it". On the other hand, $33.7 \%$ stated that "acknowledged specialists should be preferred" for TCAM. While the rate of those who experienced "negative outcomes" due to TCAM use was $21.2 \%$, the rate of those picking "I will stop using treatment alone if I believe that TCAM is necessary" was $8.1 \%$. Although the participants in the study of Ozyıldırım et al. stated that they wanted to take elective courses on TCAM, $40 . \%$ stated that they did not need medical training for applying such medical treatment methods. ${ }^{[21]}$ TCAM trainings vary from country to country, even within the same country. It is noteworthy that TCAM trainings are very common in medical schools in Thailand where almost half of the schools offer TCAM training. ${ }^{[22]}$ In another study, 39\% of the participants reported finding TCAM practices beneficial. The study by Liem demonstrated that personal experience, recommendations and referrals were effective in the participants' TCAM preference, respectively. ${ }^{[17]}$ An Australian study reported that students receiving education in different segments of healthcare differed from each other in terms of their preferred TCAM method of use, with the most preferred methods being massage, meditation, yoga and praying. ${ }^{[23]}$ A study conducted with pharmacists in Lebanon revealed a much higher rate of educational background on TCAM at the undergraduate level among the participants than in this study, reporting that more than half of the participants found TCAM practices beneficial and they believed they had fewer side effects than medical practices. ${ }^{[24]}$
In present study, the reasons for not using TCAM were as follows, respectively; a negative experience associated with TCAM practices, studying at A university, being single, high expenses, chronic illness, not having experienced any benefits in previous experiences, not having noticed the results and living mostly in urban settings; whereas sources of TCAM information such as internet, newspaper, book, and magazine, along with an educational background were effective reasons for using TCAM. The study conducted by Aktas ${ }^{[25]}$ did not find the difference in gender and location of residence significant, whereas the results of the study of Sahin et al. were contradictory to theirs. ${ }^{[26]}$ The study conducted by Armson ${ }^{[23]}$ reported that cultural characteristics were effective in TCAM use. The study conducted by Attyiat et al ${ }^{[18]}$ similarly reported that background of a previous training received by participants played a role in TCAM preference. Another available study found an association between education and gender variables and TCAM, in which the participants recommended the use of TCAM to others. ${ }^{[14]}$ The research of Mederious found that, out of all socio-demographic variables, only the female gender was an influencing factor,whereas Mwaka et al. ${ }^{[15]}$ reported the class of participants as the influencing factor. ${ }^{[27]}$ On the other hand, Samara et al. ${ }^{[28]}$ found the class, long-term location of residence and income level effective. Values and beliefs regarding religion, politics, and health affect the use of traditional treatment among individuals. ${ }^{[15]}$

It is important that health professionals know different approaches as they are the ones to moderate TCAM practices. The results of the study demonstrate that socio-demographic and educational characteristics are effective in use of TCAM methods among the undergraduate healthcare students from two different cities. It may be important to conduct research among students and healthcare professionals with different levels of health education for evaluating the impact of professional characteristics on TCAM.

\section{ETHICAL DECLARATIONS}

Ethics Committee Approval: Prior to the study, approval was obtained from the Research Ethics Committee of Bingöl University (26/03/2018:10) and the deanships of the schools where students were enrolled.

Informed Consent: All patients signed the free and informed consent form.

Referee Evaluation Process: Externally peer-reviewed.

Conflict of Interest Statement: The authors have no conflicts of interest to declare.

Financial Disclosure: The authors declared that this study has received no financial support.

Author Contributions: All of the authors declare that they have all participated in the design, execution, and analysis of the paper, and that they have approved the final version. 


\section{REFERENCES}

1. Xie H, Sang T, Li W, Li I, Gao Y, Qiu E, et al. A survey on perceptions of complementary and alternative medicine among undergraduates in China. Evidence-Based Complementary and Alternative Medicine 2020;18 https://doi.org/10.1155/2020/9091051

2. Bicer I, Yalcın Balcık P. Traditional and complementary medicine: investigation of turkey and the selected countries. Hacettepe Journal of Health Administration 2019;22(1):245-57.

3. WHO Traditional Medicine Strategy-2014-2023. https://apps.who.int/iris/ bitstream/handle/10665/92455/9789241506090_eng.pdf;jsessionid= A26C9062954CFC78B31F7FFF1DF30A04? sequence=1Accessed February 06,2020

4. http://www.who.int/medicines/ areas/traditional/definitions/

5. http://www.who.int/medicines/areas/traditional/definitions/en/

6. Sahan D, Ilhan MN. Traditional and complementary medicine practices and evaluation in public health. Gazi Journal of Health Sciences 2019:4(3):12-9

7. Orhan MF, Elmas B, Altındis S, Karagoz R, Altındis M. Traditional and complementary medicine view of family physician and pediatrists. Journal of BSHR 2019;3(Special Issue):161-7

8. Oglakcı Ilhan A, Sirekbasan S, Gürkok Tan T. Evaluation of the knowledge levels and attitudes of health services vocational school students about traditional and complementary medicine. Ankara Med J 2019;(4):736-44 doi: 10.17098/amj.651980

9. Sárváry A, Takács P, Gebriné KE, Sárváry A. Health care and social worker students' attitudes, knowledge and experience of complementary and alternative medicine and its differences between full-time and part-time students in Hungary. Kontakt / Journal of nursing and social sciences related to health and illness. 2019; doi: 10.32725/kont.2019.009

10. Park YL, Huang CW, Sasaki Y, Ko Y, Park S, Ko SG. Comparative study on the education system of traditional medicine in China, Japan, Korea, and Taiwan. Explore 2016;12(5):375-83.

11. Kılıc KN, Soylar P. Investigation of attiudes, reasons and satisfaction levels of individuals who apply to traditonal and complementary medicine practices. J Tradit Complem Med 2019;2(3):97-105

12. WHOGlobalReportonTraditionalandComplementaryMedicine,2019.141144 https://books.google.com.tr/ ooks?id=WHOyDwAAQBAJ\&printsec= frontcover $\& \mathrm{hl}=\mathrm{tr} \# \mathrm{v}=$ onepage $\& \mathrm{q}=$ turkey $\& \mathrm{f}=\mathrm{false}$

13. Simsek B, Yazgan Aksoy D, Calik-Basaran N, Taş D, Albasan D, Kalaycı MZ. Mapping traditional and complementary medicine in Turkey. Eur J Integr Med 2017;15:68-72. https://doi.org/10.1016/j.eujim.2017.09.006

14. Ibrahim O, Rashrash ME., Soliman S. Perception and utilization of complementary and alternative medicine (CAM) among University of Sharjah (UOS) students. Bulletin of Faculty of Pharmacy 2019;57(1):82-7 doi: 10.21608/bfpc.2019.7956.1011

15. Mwaka AD, Tusabe G, Garimoi CO, Vohra S, Ibingira C. Integration of traditional and complementary medicine into medical school curricula: a survey among medical students in Makerere University, Uganda. BMJ Open 2019;9:e030316. doi:10.1136/bmjopen-2019-030316

16. Ayraler A, Oztürk O, Oruç MA. Knowledge levels and attitudes of medical faculty personnel on traditional and complementary medicine. Education in Medicine Journal 2019;11(4):37-45. https://doi.org/10.21315/ eimj2019.11.4.4

17. Liem A, Newcombe P. Knowledge, attitudes, and usage of complementaryalternative medicine (CAM): A national survey of clinical psychologists in Indonesia Current Psychology 2019 https://doi.org/10.1007/s12144-01900290-1

18. Attyiat $\mathrm{HH}$, Nagwa MA, and Shaymaa SK. Effect of educational session on nursing students' knowledge and attitude toward complementary and alternative medicine. American Journal of Nursing Research 2019;7(4): 652-6. doi: 10.12691/ajnr-7-4-26.

19. Cinar F, Sengul H, Capar H, Bulut A. Causes for applications to complementary medicine practices: a scale development study. J Tradit Complem Med 2019;2(1):1-9. doI: 10.5336/jtracom.2019-64956
20. Ali I. Knowledge, awareness, and practices of complementary and alternative medicine for oral health care - a cross-sectional study among dental students in Ghaziabad, India. Journal of Advanced Medical and Dental Sciences Research 2019;7(10):156-8 doi: 10.21276/jamdsr

21. Ozyıldırım B, Ince OB, Torun P. The knowledge and attitudes towards recent regulations on complementary and alternative medicine among students and faculty members in Bezmialem University School of Medicine (BVUSOM). Indian J Tradit Know 2019;18(4):824-9

22. Peltzer K, Pengpid S. A survey of the training of traditional, complementary, and alternative medicine in universities in Thailand. Journal of Multidisciplinary Healthcare 2019;12:119-24

23. Armson A, Hodgetts C, Wright A, Jacques A, Ricciardi T, Bettinelli G et al Knowledge, beliefs, and influences associated with complementary and alternative medicine among physiotherapy and counselling students. Physiother Res Int 2019;e1825. https://doi.org/10.1002/pri.1825

24. Hijazi MA, Shatila H, El-Lakany A, Ela MA, Kharroubi S, Alameddine $M$, et al. Beliefs, practices and knowledge of community pharmacists regarding complementary and alternative medicine: national crosssectional study in Lebanon. BMJ Open 2019;9:e025074. doi:10.1136/ bmjopen-2018-025074

25. Aktas B. Attitudes of nursing students toward holistic complementary and alternative medicine. G.O.P. Taksim E.A.H. JAREN 2017;3(2):55-9 doi: 10.5222/jaren.2017.055

26. Sahin N, Aydın D, Akay B. The attitudes of nursing students towards holistic complementary and alternative medicine. Balıkesir Health Sciences Journal 2019;8(1):21-6

27. Mederious NT, Fontenelle C, Mendes Melo NA, Moringo Holanda GP, Mesquita Martins LV, Silva Godinho CC et al. Academic education in health profession programs, knowledge and use of complementary and alternative medicine (CAM) by university students. Complementary Therapies in Medicine 2019;44:189-95

28. Samara AM, Barabra ER, Quzaih HN, Zyoud SH. Use and acceptance of complementary and alternative medicine among medical students: a cross sectional study from Palestine. BMC Complementary and Alternative Medicine 2019;19:78 https://doi.org/10.1186/s12906-019-2492-x 